UDC 613.644

DOI: 10.21668/health.risk/2018.3.02.eng

Read

online

\title{
NOISE AT A WORKPLACE: PERMISSIBLE NOISE LEVELS, RISK ASSESSMENT AND HEARING LOSS PREDICTION
}

\section{E.I. Denisov}

Izmerov Research Institute of Occupational Health, 31, Prospect Budennogo, Moscow, 105275, Russian Federation

Introduction. Noise is a major occupational risk factor that causes hearing loss, one of the most widely spread occupational diseases. Recently some new standards that regulate noise at workplace have been fixed and risk assessment in the sphere has become necessary, so now it is vital to get better insights into the matter. The purpose of the work was to analyze peculiarities of occupational risk assessment performed for workplaces where there was a lot of in-plant noise taking into account international documents and national practices. Analysis of legal grounds for occupational risk assessment revealed that the most important issue in it was to determine probability of a damage to a worker's health. Only an employer can manage risks as it is him who has created them; hygienists, as per ILO Convention No. 161, are responsible for informing and giving recommendations to workers and employers on prevention measures. Methodology of occupational risk assessment that is applied in occupational medicine is a scientific foundation in the process. Analysis of risk assessment principles revealed it was necessary to determine tolerable risk, and not an acceptable one. Necessary and sufficient condition of evidential risk assessment is a hazardous factor existing at a workplace that exceeds maximum allowable concentrations or permissible exposure levels and prediction of a disease caused by this factor. According to the Guide P 2.2.1766-03, occupational risk is considered to be proven when there are data on workers' health; but as per data of working conditions assessment and criteria set forth by the Guide P 2.2.2006-5 it is thought to be only suspected. So, data obtained via specific assessment of working conditions are not sufficient to assess actual occupational risks. In 2010 the ILO issued an important document on emerging risks and new prevention forms. EU Strategic Framework on Health and Safety at Work 2014-2020 focuses on new and emerging risks as well as on probable new occupational diseases and work-related diseases. Recently some scientific works have been published that dwell on predicting risks caused by new technologies, physical, biological, psychosocial, and chemical factors. Directive 2003/10/EC issued in the EU differentiates noise standards as per urgency of measures taken, and these standards allow for means of individual protection applied to protect hearing organs; all the standards are also supplemented with practical guides. The Noise Regulations issued in Great Britain in 2005 give the following definition for risk assessment: it is determination of exposure to noise, account of risks borne by exposed groups of workers, assessment of combined effects produced by noise and ototoxic substances, as well as by noise and vibration. The author provides data that validate effects of occupational exposure to noise (the WHO, 2004) and notes that though an increase in permissible noise level from 80 to $85 \mathrm{~dB}$ is considered to be acceptable, the idea is rather controversial. The State Standard P ISO 1999-2017 on prediction of hearing loss caused by noise is well in line with the opinion expressed by the WHO experts that exposure to noise can cause disability. Conclusion. There is a logical chain for occupational risk assessment in case of noise: exposure assessment-determination of working conditions category (hazard degree) - calculation of hearing loss probability as per State Standard P ISO 1999-2017 - prevention measures - necessity to work out specific programs aimed at hearing preservation recommended by the ILO. These programs can reduce risk and extra-aural noise effects; they should be drawn up as Sanitary rules or a State Standard and help to preserve health and provide safe and productive work.

Key words: noise, occupational medicine, working conditions, hearing loss, risk assessment, prediction, prevention.

Noise is one of the most widely spread adverse factors at a workplace. As per data provided by the Federal State Statistics Service ${ }^{1}$, in 2016 $38.5 \%$ workers were employed at work places with adverse and hazardous working conditions; $18.2 \%$ out of them were exposed to noise, ultraand infrasound; that is, almost each $5^{\text {th }}$ workplace is hazardous as per acoustic factors. $\mathrm{Pa}-$

(C) Denisov E.I., 2018

Eduard I. Denisov - Doctor of Biological Sciences, Professor, Senior Researcher, Winner of the Award granted by the RF Government in the sphere of science and technology and F.F. Erisman's Award in the sphere of hygiene granted by the Presidium of the Russian Academy of Sciences (e-mail: denisov28@yandex.ru; tel.:+7 (903) 194-63-21). \footnotetext{
Russian).

${ }^{1}$ Russian Statistics Yearbook. 2017: Statistic data collection / Federal State Statistics Service. Moscow, 2017, 686 p. (in
} 
thologies caused by physical factors occupy the first place in occupational morbidity structure; their share increased in 2017 and reached $47.82 \%$. Hearing loss caused by noise and diagnosed as sensorineural deafness prevails among such pathologies as its share amounts to 58.84 $\%^{2}$.

The analysis performed for five basic economic branches (mining; processing industries; production and supply of electricity, water, and gas; transportation and communication; construction) has shown that hygienic standards are not met at workplaces; each $10^{\text {th }}$ noncompliance was related to noise, and each $5^{\text {th }}$ occupational disease was caused by it [1].

As per data provided by the WHO, 360 million people worldwide (5\% of the world population) live with disabling hearing loss. There are a lot of unemployed among such people or they frequently have very low-paid occupations. Hearing loss among elderly people leads to social isolation, anxiety, depression, a decrease in cognitive abilities, and dementia ${ }^{3}$.

As per data of the US National questioning on healthcare, $23 \%$ out of workers exposed to noise had hearing troubles, 5\% suffered from tinnitus, and $9 \%$ had both conditions; the same parameters among those who had never been exposed to noise amounted to $7 \%, 5 \%$, and $2 \%$ correspondingly $(\mathrm{P}<0.0001)[2]$.

Issues related to etiology, pathogenesis, diagnostics, and prevention of noise-induced hearing loss have been studied [3, 4]. Validity of extra-aural noise effects is becoming higher. Earlier non-specific noise effects weren't always considered to be proven [5]; but recent research has revealed that exposure to noise significantly correlates with cardiovascular diseases, notably, arterial hypertension, although a correlation between noise and mortality caused by cardiovascular diseases turned out to be weak [6].A great- er attention is paid to traumatism as an occupational risk factor [7], especially for noisy occupations [8], as well as to fitness for work responsibilities fulfillment as per hearing or so called "hearing fitness" [9]. Hearing loss criterion in its essence is not primarily oriented at health preservation, but at providing safe and efficient work, especially in case of occupations that involve great neuro-emotional tension (public transport drivers, civil aviation pilots etc.) [10, $11]$.

The question of risk assessment associated with noise exposure at a workplace becomes truly vital in relation to approval on SanitaryEpidemiologic Rules and Norms SanPiN 2.2.4.3359-16 $6^{4}$, that set maximum permissible noise levels at 80 and $85 d B(A)$ and require obligatory risk assessment in the last case, as well as introduction of the State Standard GOST R ISO $1999-2017^{5}$

The research goal was to analyze peculiarities of occupational risks assessment for workers exposed to noise at their workplaces taking into account international documents and national practices.

Legal grounds for occupational risk assessment. A concept of "risk" first appeared in occupational health 50 years ago in a document issued by the International Organization for Standardization (ISO), namely ISO/R 1999:1971 recommendation $^{6}$ on how to assess occupational exposure to noise in order to preserve a person's hearing. There was a table in the document with "Risk, \%" column as hearing loss probability in per cent that depended on a noise level in $\mathrm{dB}(\mathrm{A})$ and duration of service in noisy conditions. The International Labor Organization (ILO) fixed in its Convention No. $148^{7}$ ((ratified by the Russian Federation), Clause 3, that "the term noise covers all sound which can result in hearing impairment or be harmful to health or otherwise

\footnotetext{
${ }^{2}$ On sanitary-epidemiologic welfare of the population in the Russian Federation in 2017: State Report. Moscow, The Federal Service for Surveillance over Consumer Rights Protection and Human Well-being Publ., 2018, 268 p. (in Russian).

${ }^{3}$ Prevention of deafness and hearing loss: The Secretariat Report (A70/34 On May 04, 2017). World Health Organization. Available at: http://apps.who.int/gb/ebwha/pdf files/WHA70/A70 34-ru.pdf (access date: 14.07.2018) (in Russian).

${ }^{4}$ SanPiN 2.2.4.3359-16. Sanitary-Epidemiologic Rules and Norms for physical factors at workplaces. KODEKS: an electronic fund of legal and reference documentation. Available at: http://docs.cntd.ru/document/420362948 (access date: 14.07.2018).

${ }^{5}$ State Standard R ISO 1999-2017. Acoustics. Assessment of hearing loss caused by exposure to noise at workplaces. KODEKS: an electronic fund of legal and reference documentation. Available at: http://docs.cntd.ru/document/1200157242 (access date: 14.07.2018).
} 
dangerous". The Convention introduced a concept of occupational risk. Clause 4 states that "measures be taken for the prevention and control of, and protection against, occupational hazards in the working environment due to ... noise and vibration".

As per Clause 8 of the Convention, "The competent authority shall establish criteria for determining the hazards of exposure to air pollution, noise and vibration in the working environment and ... shall specify exposure limits on the basis of these criteria. The criteria and exposure limits shall be established, supplemented and revised regularly in the light of current national and international knowledge and data, taking into account as far as possible any increase in occupational hazards resulting from simultaneous exposure to several harmful factors at the workplace."

The RF Labor Code ${ }^{8}$ contains Clause 209 that defines an occupational risk as "a probability of damage to health caused by exposure to adverse and (or) hazardous occupational factors when a worker fulfils his or her duties according to a labor contract or in any other cases identified by the present Code or other federal laws. A procedure for occupational risk assessment is to be fixed by a federal executive body that is responsible for state policy development and legal regulation in the sphere of labor taking into account opinions expressed by the Russian tripartite commission for regulation of social and labor relations".

Occupational risks management is a set of activities that are components in the system of labor protection management; they include measures aimed at detecting, assessing, and reducing occupational risks.

Therefore, the primary task in occupational risk assessment is to determine probability of damage to health. A procedure for occupational risk assessment is fixed by the RF Labor Ministry taking into account opinions expressed by The Tripartite Commission. Occupational risks management as a set of organizational and technical activities is a part of the labor protection system and it goes beyond responsibilities of hygienists. Therefore, a risk is managed by those who create it, in this case, by employers. Hygienists act within their competence determined in the ILO Convention No. 161 or "Occupational Health Services Convention" (not ratified by the Russian Federation); they give advice to workers on risks at their workplaces, protection and prevention measures; and they give advice to employers on prevention measures required to manage risks.

Methodology of occupational risks assessment in occupational health is scientific grounds for hygienic assessment and prevention. Its foundations were set 25 years ago in research supervised by Academician N.F. Izmerov [12]; they were then generalized in a reference guide [13]; and its principles, methods and criteria were systematized in further research $^{9}$ [14]. These domestic works (co-written with other scientists) were given the Russian Federation Government Award in science and technology (2002) and F.F. Erisman's Award in Hygiene granted by the Presidium of the Russian Academy of Medical Sciences (2004).

The methodology spots out a priori hygienic and a posteriori medical and biological occupational risks assessment [13]. Its advantages are the scales with quantitative assessment criteria: a) a risk doubles per each harm category of working conditions in the Guide R 2.2.2006- $05^{10}$ and b) an occupational disease index also doubles per each harm category of working conditions ${ }^{11}$.

In particular, the Guide R 2.2.2006-05 implies scales for vibration and acoustic factors

${ }^{6}$ ISO/R 1999:1971. Acoustics - Assessment of occupational noise exposure for hearing conservation purposes. International Organization for Standardization. Available at: https://www.iso.org/ru/standard/56849.html (access date: 14.07.2018) (in Russian).

${ }^{7}$ Working Environment (Air Pollution, Noise, and Vibration) Convention: Convention No. 148. KODEKS: an electronic fund of legal and reference documentation. Available at: http://docs.cntd.ru/document/1900829 (access date: 14.07.2018) (in Russian).

${ }^{8}$ Labor Code of the Russian Federation. KODEKS: an electronic fund of legal and reference documentation. Available at: http://docs.cntd.ru/document/901807664 (access date: 14.07.2018) (in Russian).

${ }^{9}$ Occupational risk: Electronic interactive reference catalogue. Edited and compiled by a member of Russian Academy of Science, Academician N.F. Izmerov, Professor E.I. Denisov, Doctor of Biological Sciences I.V. Stepanyan. Available at: http://medtrud.com/ (access date: 14.07.2018) (in Russian). 
that have steps for noise, whole-body and handarm vibration equal to 10,6 and $3 \mathrm{~dB}$ respectively and it reflects their different biologic efficiency (doubling of loudness, kinematic parameter, and a dose accordingly).

A significant task in the methodology is to determine a probability of occupational and work-related diseases as well as to account their categories of risk, severity of illness; and degree of work-relatedness (causality) as it allows to obtain single-number indexes that are very convenient for managing risks ${ }^{12}$.

Risk assessment principles: risk tolerability or acceptability. There is a principle in the world practice stating that a polluter has to pay or "polluter pays principle" (PPP); it was introduced by a recommendation of the Organization for Economic Cooperation and Development in 1972; it was accepted by the European Union in 1987 and included as Principle No. 16 in Rio-de-Janeiro Declaration of 1992. There is another principle, a precautionary principle, approved by the European Union $^{13}$ in 2000 and UNESCO ${ }^{14}$ in 2005. The principles allow to manage probable risks in a case when there aren't enough scientific data, for example, risks related to nanotechnologies, genetically modified organisms, etc.

There are three possible attitudes towards risks, namely avoidance, acceptance, and regulation; world practice mostly inclines towards regulation, or risk management [as per 13], that was earlier called prevention.

First works on risks were published in the
UK and the USA [15-17]. Foreign researchers in their works on risk assessment procedures examined a number of criteria for risks acceptance/tolerance such as ALARA, ALARP, FAPRA and others, that differed only in their legal subtleties. ALARA principle (the abbreviation for As Low As Reasonably Achievable) was formulated in 1954 by the International Commission on Radiological Protection. It was further developed in ALARP principle, or "As Low As Reasonably Practicable".

In 1974 the "Health and Safety etc. at Work Act" was issued in the UK ${ }^{15}$ according to it, people who control production premises or activities are to reduce risks as per SFARP criterion (the abbreviation for So Far As is Reasonably Practicable). The UK Health and Safety Executive issued a controversial document "Reducing risks, protecting people" [17] where it fixed criteria for risks tolerance as per the following gradations: unacceptable, tolerable, quite acceptable, negligible, and we can see that the terms are rather inconsistent. Since there is a principle in occupational health and industrial ecology stating that "Acceptance of a priori hazard and harm for health is incompatible with zero risk principle and implies there is a residual risk determined by deontology and prevention capabilities" [as per 13], it is necessary to speak about social tolerance of occupational risks $[13, p$. 100].

The Guide R 2.2.1766-0311 sets an association between working conditions categories and occupational risks categories: optimal 1 catego-

${ }^{10} \mathrm{R}$ 2.2.2006-05. The Guide on hygienic assessment of factors related to working environment and labor process. $\mathrm{KO}$ DEKS: an electronic fund of legal and reference documentation. Available at: http://docs.cntd.ru/document/1200040973 (access date: 10.07.2018) (in Russian).

${ }^{11} \mathrm{R} 2.2 .1766-03$. The Guide on assessment of occupational risks for workers' health. Organizational and methodical grounds, principles, and assessment criteria. Guide. KODEKS: an electronic fund of legal and reference documentation. Available at: http://docs.cntd.ru/document/9019020533 (access date: 10.07.2018) (in Russian).

${ }^{12}$ Risk management methodology in occupational medicine: hygienic assessment of working conditions, prediction and causation of occupational diseases related to work (harmonized collection of methodological materials) / approved by the Scientific Council No. 45 "Medical and ecological issues related to workers' health" of the Russian Academy of Medical Sciences. Moscow, NII MT RAMS Publ., 2012, 23 p. (in Russian).

${ }^{13}$ Communication from the Commission on the precautionary principle. Brussels, 2.2.2000, COM (2000) 1 final. Available at: https://eur-lex.europa.eu/LexUriServ/LexUriServ.do?uri=COM:2000:0001:FIN:EN:PDF (access date: 10.07.2018)

${ }^{14}$ UNESCO. The Precautionary Principle. World Commission on the Ethics of Scientific Knowledge and Technology (COMES). Available at: http://unesdoc.unesco.org/images/0013/001395/139578e.pdf (access date: 10.07.2018) (in Russian).

${ }^{15}$ Health and Safety at Work etc. Act 1974. Available at: http://www.legislation.gov.uk /ukpga/1974/37/contents (access date: 10.07.2018). 
ry- no risk; acceptable 2 - negligible (tolerable) risk; hazardous 3.1- small (moderate) risk; hazardous 3.2- average (considerable) risk; hazardous 3.3- high (intolerable) risk; dangerous (extreme) 4- ultra high risk and risk for life that is characteristic for this particular occupation. And we can see that here a term "tolerance", and not "acceptance" is applied. Therefore, according to risk management principle (Clause 209 of the RF Labor Code) we should rely on a concept of risk tolerance, and not risk acceptance.

OEL or risk assessment? For many years, a paradigm based on OEL (MPC and MPL) was a central one in occupational hygiene, its main assumption being that conformity to them was obligatory and possible at any workplace and it could guarantee health preservation. Indeed, MPC and MPL are true bases of safety but they are far from being always adhered to. Therefore, it became necessary to assess consequences of their violation, to determine prevention tactics and measures of social protection for those who have to work under adverse conditions. Finding solutions to these tasks required new theories that include risk assessment and management and that have been developing rapidly over recent years. As social and economic changes occurred in the country, and it made a scientific paradigm in occupational health shift from MPC/MPL to a methodology of occupational risk assessment [13].

As opposed to traditional hygienic assessment of working conditions when all values higher than hygienic standards were fixed without taking into account an extent to which they were higher or what possible consequences for health it would mean, risk assessment pays greater attention to quantitative estimation of probable damage to health in order to choose efficient risk management activities, i.e. prevention [13].

MPC and MPL as bases of hygiene don't give any information on probability or severity of consequences, i.e. risk assessment. There is a true paradox here: risk assessment is based on MPC and MPL, however, MPC and MPL are obligatory but not sufficient for risk assessment. A "dose - effect" relationship is sufficient here as it gives grounds for predicting probable health disorders.
The ILO in its "Technical and ethical guidelines for workers' health surveillance" [18]. item 2.7 , states that "surveillance programs should be used for prevention purposes and in particular to predict the occurrences of occupational injuries and diseases". And here (item 3.19) "priority should be given to environmental (exposure) limits over biological (biological exposure limits) criteria". That is, medical examinations with an occupational disease prediction (given in italics by us - E.D.) are a basis of prevention activities with priority given to criteria of working environment assessment, i.e. MPC/MPL.

Consequently, evidence-based risk assessment in full conformity with the letter and the spirit of the requirements fixed by the RF Labor Code (Clause 209 and others) and the ILO documents should include obligatory and sufficient such components as assessment of a degree of excess the MPC/MPL by harmful factor at a workplace and prediction of probability of an occupational disease caused by this factor.

Special assessment of working conditions (SAWC) according to the Federal Law NO. $\mathbf{4 2 6}^{16}$. Clause 13 of the Law contains the following definition: Special assessment of working conditions is a unified set of activities aimed at identifying adverse and (or) hazardous factors related to working environment and working process and assessing their effects on a worker taking into account deviations in their actual values from fixed standards (hygienic standards) existing for these working conditions and application of individual and collective protection means".

SAWC replaces a certification of workplaces and state examination of working conditions and takes into account actual impacts on a worker's body exerted by adverse and (or) hazardous factors related to working environment and working process. Categories (sub-categories) of working conditions at specific workplaces are fixed as per SAWC results; these categories are taken into account when insurance fees are paid to pension funds, compensations are given to workers, individual protection means provided, medical examinations organized, occupational risks assessed, accidents and occupational diseases investigated, etc.

SAWC is performed according to an established procedure ${ }^{17}$, that includes: 1) identifi- 
cation of potentially adverse and (or) hazardous occupational factors; 2) examinations (tests) and measurements of such factors; 3) assignment of working conditions into a specific category (subcategory) according to a degree of their adverse and (or) hazard health effects; 4) presentation of results. In spite of several drawbacks [19], SAWC is an acting system for occupational risk assessment.

It should be noted that, according to the Guide P R 2.2.1766-03 ${ }^{11}$, an occupational risk is considered to be proven (category 1A) on the basis of data on workers' health obtained via periodical medical examinations; while results of working conditions hygienic assessment performed as per criteria given in the Guide $R$ 2.2.2006- $05^{10}$ are to be considered only as a suspected risk (category 2). So, if one wants to assess an actual occupational risk, SAWC results are not sufficient and they should be supplemented with data obtained via periodical medical examinations.

The European Union strategy on health and safety at work (2014-2020) and new emerging risks. A framework strategy adopted in the $\mathrm{EU}^{18}$ highlighted problems small and middle-sized businesses had to face, new emerging risks, and ageing of workforce. There are 7 strategic goals outlined in the document, and No. 5 goal directly focuses on ageing of workforce, new and emerging risks (and new occupational diseases) as well as prevention measures. The purpose of the strategy is to promote better working conditions and processes, higher labor satisfaction, higher competitiveness of European companies and lower expenses borne by social insurance systems. A most significant part in the EU strategy is recognition of new and emerging risks and new occupational and work-related diseases. There isn't any similar document issued in our country.

We should mention a most significant doc- ument issued by the ILO that dwells on emerging risks and new prevention techniques in a rapidly changing labor world [20]. It was followed by works on prediction of new risks caused by new technologies [21] as well as by physical [22], biological [23], psychosocial [24], and chemical [25] factors.

New and emerging physical risk factors are linked with a role that physical loads play in development of disorders in the musculoskeletal system; such risks also include those caused by noise, vibration, thermal factors, ionizing radiation, machinery and equipment etc. Such risks can also emerge from absence of physical activity, or combined effects produced by physical loads and psychosocial risks; they can be related to multiple factors or caused by a complex interaction within "a man - a machine" system etc. [22]. New biological risks are linked with the global epidemiologic situation, impacts exerted by antimicrobic-resistant pathogens in public healthcare and food industry, as well as with endotoxins, mold fungi at workplaces, solid wastes etc. [23]. Works are being published on risk analysis and prediction in relation to advanced processing technologies [26].

It is obvious that all the above-mentioned issues ought to be examined in depth bearing in mind future prospects for research; there is a wide range of them, starting from disorders in the musculoskeletal system and to combined effects by physical and psychosocial loads, issues related to "a man - a machine" interactions etc.

The EU Guide on occupational risks assessment [27] consists of 4 parts: 1) introduction, definitions, and procedures, 2) basics (data collection, detection of hazards, risk assessment, prevention measures, documenting), 3) checklists (safety rules, chemicals, noise, vibration, illumination, stress at work), 4) detection of hazards and prevention measures for specific activities (work in an office, construction, food industry, wood pro-

\footnotetext{
${ }^{16}$ On special assessment of working conditions: The RF Federal Law issued on December 28, 2013, No. 426. Konsultant Plus. Available at: http://www.consultant.ru/document/cons_doc_LAW_156555/ (access date: 09.07.2018) (in Russian).

${ }^{17}$ On Approval of Procedure for conducting a special assessment of working conditions, Classifier of adverse and (or) hazardous production factors, reporting form on a specific assessment of working conditions and instructions how to fill it in: The Order issued by the RF Ministry for labor and Social Protection on January 24, 2014 No. 33n. Garant. Available at: http://base.garant.ru/70583958/ (access date: 09.07.2018).

${ }^{18}$ Communication from the Commission to the European Parliament, the Council, the European economic and social committee and the Committee of the regions on an EU strategic framework on health and safety at work 2014-2020 Available at: http://ec.europa.eu/social/BlobServlet?docId=11828\&langId=en (access date: 09.07.2018).
} 
cessing, car repairing, agriculture, open-cut mines). This Guide can be useful for both employers and their employees as it explains basic issues related to labor protection and occupational medicine in such a way that they can be understood easily. However, it doesn't contain any quantitative criteria of occupational risks assessment or any literature reference and it makes its scientific value rather limited.

The EU Directive 2003/10/EC on noise ${ }^{19}$. Item 7 in the preamble contains the following: "to introduce measures protecting workers from the risks arising from noise owing to its effects on the health and safety of workers, in particular damage to hearing".. Clause 4 "Determination and assessment of risks" states in item 6e that "...any indirect effects on workers' health and safety resulting from interactions between noise and warning signals or other sounds ... need to be observed in order to reduce the risk of accidents". Thus the Directive regulates limitation of noise required for both hearing preservation and labor safety.

The document also fixes exposure limit values and exposure action values in respect of the daily noise exposure levels and peak sound pressure. The lower and upper exposure action values require some measures to be taken, and the exposure limit values suppose that personal protection of hearing organs ought to be applied (Table).

Permissible noise levels as per the Directive 2003/10/EC

\begin{tabular}{|c|l|c|c|c|}
\hline № & \multicolumn{1}{|c|}{ Parameter } & $L_{\mathrm{EX}}, 8 \mathrm{~h}$ & $P_{\text {peak }}$ & $\begin{array}{c}\mathrm{dB}(\mathrm{C}) \text { re. } \\
20 \mu \mathrm{Pa}\end{array}$ \\
\hline 1 & $\begin{array}{l}\text { Exposure limit } \\
\text { values }\end{array}$ & $\begin{array}{c}87 \mathrm{~dB} \\
(\mathrm{~A})\end{array}$ & $200 \mathrm{~Pa}$ & $140 \mathrm{~dB}$ \\
\hline 2 & $\begin{array}{l}\text { Upper exposure } \\
\text { action values }\end{array}$ & $\begin{array}{c}85 \mathrm{~dB} \\
(\mathrm{~A})\end{array}$ & $140 \mathrm{~Pa}$ & $137 \mathrm{~dB}$ \\
\hline 3 & $\begin{array}{l}\text { Lower exposure } \\
\text { action values }\end{array}$ & $\begin{array}{c}80 \mathrm{~dB} \\
(\mathrm{~A})\end{array}$ & $112 \mathrm{~Pa}$ & $135 \mathrm{~dB}$ \\
\hline
\end{tabular}

As one can see from the Table (the difference between lines 1 and 2-3), when hearing protectors (earmuffs, earplugs, helmets etc.) are applied, their expected efficiency is within 2-7 $\mathrm{dB}$. It corresponds to a 1.15-1.6 times decrease in noise loudness and this decrease can be subjectively noticeable [13].

One should also mention "Non-binding guide to good practice for the application of Directive 2003/10/EC" ${ }^{\prime 20}$; this guide dwells on issues related to measuring and assessing exposure to noise as well as prevention measures. Therefore, there are noise standards in the EU that are differentiated as per urgency of measures to be taken and that account for PPE for hearing organs; these are supplemented with a guide to good practice.

An experience of Great Britain on risk assessment of noise at work. "Control of Noise at Work Regulations" ${ }^{21}$ fix a procedure for risk assessment in case of noise exposure at a workplace. An employer is to assess a health risk for workers caused by noise in order to determine what measures should be taken to meet the requirements set forth by the Regulations. And here noise is to be estimated via observations over working practices and taking into account data on possible noise levels generated by used equipment; when necessary, an employer should measure noise levels and compare them with the existing standards.

Risk assessment includes considering the following: a) level, type, and duration of exposure to noise, including exposure to a peak sound pressure: b) impacts exerted by noise on workers whose health is at specific risk of such exposure; c) any consequences for workers' health and safety that result from interactions between noise and ototoxic substances or between noise and vibration; d) any indirect consequences for workers' health and safety that result from interactions between noise and acoustic alarms or any other sounds that are to be heard to reduce risks at a workplace.

So, risk assessment here involves determina-

\footnotetext{
${ }^{19}$ On the minimum health and safety requirements regarding the exposure of workers to the risks arising from physical agents (noise) (The 17th separate Directive in Clause 16(1) of Directive 89/391/EEU): Directive by the European Parliament and the European Union Council 2003/10/EU issues on February 6, 2003. Available at: http://docs.pravo.ru/document/view/44436558/50529867/ (access date: 09.07.2018) (in Rissian).

${ }^{20}$ Non-binding guide to good practice for the application of Directive 2003/10/EC. Luxembourg: Office for Official Publications of the European Communities, 2008, 169 p. DOI: 10.2767/61482

${ }^{21}$ Control of Noise at Work Regulations 2005. Available at: http://www.legislation.gov.uk/uksi/2005/1643/contents/made (access date: 09.07.2018)
} 
tion of noise exposure, account of risks for vulnerable groups of workers, assessment of combined effects produced by noise and ototoxic substances, as well as by noise and vibration.

New noise standards. New SanitaryEpidemiologic Rules and Norms SanPiN 2.2.4.3359-16 ${ }^{4}$ fix maximum permissible noise levels for certain industries at 80 and $85 \mathrm{dBA}$ provided that acceptability of risk for workers' health is confirmed by occupational risks assessment and results obtained during periodical medical examinations of people who are exposed to noise higher than $80 \mathrm{dBA}$. The document also requires prohibition of any works under noise levels higher than 80 $\mathrm{dBA}$. These statements raise a number of issues.

Validity of OEL (MPL) for noise. The WHO document that focuses on assessing burden of diseases caused by work-related hearing loss [28] contains Table 1 "Assessment of reported responses to occupational noise exposure" where evidence is considered to be limited for performance, biochemical and immune effects, and birth weight, and where it is considered to be sufficient for the following:

- annoyance at noise being $<55 d B(A)$ in offices and $<85 d B(A)$ in industry,

- hypertension at 55-116 $d B(A)$,

- hearing loss (adults) at $75 d B(A)$ and (unborn children) at $<85 d B(A)$.

In relation to that we can't agree with some authors who state that it is quite acceptable to increase MPL for noise from 80 to $85 d B(A)$ : "In-plant noise equal to $80 d B(A)$ is theoretical minimum exposure that doesn't cause higher risks of hearing loss. Compliance with the noise standard equal to $85 d B(A)$ fully allows to reduce prevalence of noise-induced hearing loss" [29]. This tirade contradicts arguments given by the WHO.

After the State Standard GOST R ISO $1999-2017^{5}$ has been introduced, it is advisable to make some corrections into item 3.2.6 of the SanPiN 2.2.4.3359-16 ${ }^{4}$ and fix that occupational risk assessment is to be performed via calcula- tion of hearing loss probability for workers and audiometric testing during periodical medical examinations when noise level is higher than 80 $d B(A)$. These measures will reduce both risks of hearing loss and extra-aural effects of noise.

A new standard for hearing loss prediction, GOST R ISO 1999-2017 $^{5}$. There is a specific risk assessment system that has developed in relation to the issue of noise in world literature and practices; this system differs from that applied when chemical factors are assessed [30] and is based on predicting probability of hearing loss as an officially recognized occupational disease caused by noise. It started as far back as in 1971 when the Recommendation ISO/R 1999:1971 was first published; it then became the Standard ISO 1999:1975, which was then revised as ISO 1999:1990 and finally as ISO 1999:2013, and then introduced in Russia as the State Standard GOST R ISO 1999-2017. As opposed to the first edition, the Standard doesn't contain any definite formula for risk assessment, but it determines techniques that can be applied within national systems to predict hearing loss.

The Standard introduces a number of notions that are very important for occupational health ${ }^{22}$ :

- hearing loss - deviation or a change for the worse of the threshold of hearing from normal;

- hearing disability - effect of hearing loss on activities in daily living (Note 1 to entry: This is sometimes called "activity limitation" (WHO);

- risk of hearing disability - percentage of a population sustaining hearing disability;

- risk of hearing disability due to noise risk of hearing disability in a noise-exposed population minus the risk of hearing disability in a population not exposed to noise but otherwise equivalent to the noise-exposed population.

These terms enrich the methodology of occupational risks assessment. It is also important that the Standard adheres to the WHO position on disability that can be a consequence of expo-

\footnotetext{
${ }^{22}$ Original text to be found in ISO 1999:2013 Acoustics - Estimation of noise-induced hearing loss. Online Browsing Platform. Available at: https://www.iso.org/obp/ui/\#iso:std:iso:1999:ed-3:v1:en (access date: 09.07.2018).

${ }^{23}$ State Standard R ISO /IEC 31010-2011. Risk management. Risk assessment techniques. Moscow, Standartinform Publ., 2012, 74 p. (in Russian).
} 
sure to noise [28].

Conclusion. Fundamentals of risk management have been developed in great detail and documented in standards ${ }^{23}$ and guides, starting from pragmatic $[31,32]$ to academic ones with economic and psychosocial estimates [33] and taking into account occupational and nonoccupational exposures [34].

There is Guidance on risk assessment at work [35] and a standard on risk assessment techniques [36] adopted in the EU; Health and Safety Executive (HSE) in the UK has developed "Risk Assessment Tool and Guidance (including Application Guidance)" [37].

But the issue of noise at a workplace has its peculiarities because it is related not only to health but also safety $[10,11]$, and involves not only risk assessment but also prediction of possible effects. Starting from early works with predictions as per Monte Carlo method [38], the methodology of occupational risks assessment is so well grounded by scientific works, developments, and state standards, that it makes the noise issue truly international. We can compare it to a project by the US National Institute for Occupational Safety and Health (NIOSH) dedicated to assessment of new risk factors (including nano-materials) suggested for general discussions [39].

A logic chain for noise is as follows: exposure assessment - determination of working conditions category (degree of harm) - calculation of hearing loss probability as per GOST R ISO - a set of prevention measures (PPE, rest rooms, vitamin prophylaxis etc.); all these require development of Hearing Conservation Programs recommended by the ILO and documented as sanitary rules or a state standard.

Thus, in relation to State Standard GOST R ISO 1999-20175 introduction it is advisable to make changes into item 3.2.6 of the Sanitary-Epidemiologic Rules and Norms 4 and state that occupational risk assessment is to be performed via calculation of hearing loss probability for workers and their audiometric testing during periodical medical examinations when noise level is higher than $80 \mathrm{~dB}(\mathrm{~A})$. These measures will reduce both risks of hearing loss and extra-aural noise effects. In a very distant future, "deserted work" in the noisy conditions will be performed by the so-called cyberphysical systems (robots and autonomous devices based on artificial intelligence), which is envisaged by the course of digitalization of the Russian economy.

\section{Conclusions:}

1. From the standpoint of evidence-based medicine, an adequate assessment of occupational risk under exposure to noise should include both an assessment of the excess of the maximum permissible level and a prediction of the probability of hearing loss with audiometric control during a periodic medical examinations.

2. Occupational risk assessment under exposure to noise in world practice includes detection of hazard sources, exposure assessment, determination of vulnerable workers' groups (teenagers, pregnant and recently delivered women, breast-feeding mothers, workers with chronic diseases, migrants, and others) and selection of prevention measures.

3. Noise exposure monitoring, a prediction of hearing loss probability, audiometric control during periodical medical examinations, and prevention activities are to be fixed as a set of measures in programs for hearing preservation documented as a state standard, a system of labor safety standards, or sanitary-epidemiologic requirements.

Gratitude. The author dedicates this work to the memory of Academician Nikolay Fyodorovich Izmerov who always provided support; a lot of papers on occupational risks, a priority knowledge sphere in hygienic sciences, were written by the author together with him.

Funding. Our research was not granted any sponsors' support.

A conflict of interests. The authors state there is no conflict of interests.

\section{References}

1. Kostenko N.A. Usloviya truda i professional'naya zabolevaemosti v nekotorykh vidakh ekonomicheskoi deyatel'nosti Rossiiskoi Federatsii v 2004-2013 gg. [Working conditions and occupational morbidity in 
some branches of economic activity of Russian Federation in 2004-2013]. Meditsina truda i promyshlennaya ekologiya, 2015, no. 4, pp. 43-45 (in Russian).

2. Masterson E.A., Themann C.L., Luckhaupt S.E., Calvert G.M. Hearing difficulty and tinnitus among U.S. workers and non-workers in 2007. Am. J. Ind. Med., 2016, vol. 59, pp. 290-300. DOI: 10.1002/ajim.22565

3. Zinkin V.N., Sheshegov P.M., Chistov S.D. Klinicheskie aspekty professional'noi sensonevral'noi tugoukhosti akusticheskogo geneza [The clinical aspects of occupational sensorineural impairment of hearing of the acoustic origin]. Vestnik otorinolaringologii, 2015, vol. 80, no. 6, pp. 65-70. DOI: 10.17116/otorino201580665-70

4. Le T.N., Straatman L.V., Lea J., Westerberg B. Current insights in noise-induced hearing loss: a literature review of the underlying mechanism, pathophysiology, asymmetry, and management options. J. Otolaryngol. - Head and Neck Surg., 2017, vol. 46, pp. 41. DOI: 10.1186/s40463-017-0219-x

5. Occupational exposure to noise: evaluation, prevention and control. In: B. Goeltzer, C.H. Hansen, G.A. Sehrndt eds. Dortmund, Germany: WHO, 2001, 336 p.

6. Skogstad M., Johannessen H.A., Tynes T., Mehlum I.S., Nordby K.-C., Lie A. Systematic review of the cardiovascular effects of occupational noise. Occupational Medicine, 2016, vol. 66, no. 6, pp. 1-16. DOI: 10.1093/occmed/kqw113

7. Bukhtiyarov I.V., Izmerov N.F., Tikhonova G.I., Churanova A.N. Proizvodstvennyi travmatizm kak kriterii professional'nogo riska [Occupational injuries as a criterion of professional risk]. Problemy prognozirovaniya, 2017, no. 5, pp. 140-149 (in Russian).

8. Toppila E., Pyykkö I., Pääkkönen R. Evaluation of the increased accident risk from workplace noise. Int. J. Occup. Saf. Ergon. (JOSE), 2009, vol. 15, no. 2, pp.155-162.

9. Tufts J.B., Vasil K.A., Briggs S. Auditory fitness for duty: A review. J. Am. Acad. Audiol., 2009, vol. 20, pp. 539-557. DOI: 10.3766/jaaa.20.9.3

10. Denisov E.I., Adeninskaya E.E., Eremin A.L., Kur'erov N.N. Professional'naya poterya slukha problema zdorov'ya i bezopasnosti [Occupational deafness - problem of health and safety]. Meditsina truda $i$ promyshlennaya ekologiya, 2014, no. 7, pp. 45-47 (in Russian).

11. Sovershenstvovanie kriteriev poteri slukha ot shuma i otsenka professional'nogo riska / I.V. Bukhtiyarov, E.I. Denisov, N.N. Kur'erov, L.V. Prokopenko, M.V. Bulgakova, O.O. Khakhileva [Improvement of noise-induced hearing loss criteria and occupational risk assessment]. Meditsina truda i promyshlennaya ekologiya, 2018, no. 4, pp. 1-9 (in Russian).

12. Izmerov N.F., Kaptsov V.A., Denisov E.I., Ovakimov V.G. Problema otsenki professional'nogo riska $\mathrm{v}$ meditsine truda [Evaluation of occupational diseases according to risk and severity categories]. Meditsina truda i promyshlennaya ekologiya, 1993, no. 3-4, pp. 1-4 (in Russian).

13. Professional'nyi risk dlya zdorov'ya rabotnikov [Occupational health risk]. In: N.F. Izmerov, E.I. Denisov, eds. Moscow, Trovant Publ., 2003, 448 p. (in Russian).

14. Izmerov N.F., Denisov E.I. Otsenka professional'nogo riska v meditsine truda: printsipy, metody i kriterii [An assessment of the occupational risk in the medical sphere: principles, methods and criteria]. Vestnik Rossiiskoi akademii meditsinskikh nauk, 2004, no. 2, pp.17-21 (in Russian).

15. Risk: Analysis, Perception and Management. Report of the Royal Society Study Group. London, 1992. Available at: https://royalsociety.org/topics-policy/publications/1992/risk/ (18.07.2018).

16. Vincent T.C., Milley W.M. Risk assessment methods: approaches for assessing health and environmental risks. New York: Plenum Press, 1993, 267 p.

17. Reducing risks, protecting people. HSE's decision-making process (HSE.r2p2). Crown, 2001, 88 p.

18. Technical and ethical guidelines for workers' health surveillance (OSH No 72). Geneva, International Labour Office, 1998, $41 \mathrm{p}$.

19. Prokopenko L., Lagutina A., Kur'erov N. Metodika trebuet peresmotra [The procedure needs to be revised]. Okhrana truda i sotsial'noe strakhovanie, 2014, no. 9, pp. $72-77$ (in Russian).

20. Emerging risks and new patterns of prevention in a changing world of work. Geneva, International Labour Organization, 2010, $19 \mathrm{p}$.

21. Ellwood P., Reynolds J., Duckworth M. Green jobs and occupational safety and health: Foresight on new and emerging risks associated with new technologies by 2020. Luxembourg, European Agency for Safety and Health at Work, 2014, 40 p. DOI: 10.2802/92105

22. Flaspöler E., Reinert D., Brun E. Expert forecast on emerging physical risks related to occupational safety and health. Luxembourg, European Agency for safety and health at work, 2005, 76 p. 
23. Expert forecast on emerging biological risks related to occupational safety and health. Luxembourg, European Agency for Safety and Health at Work, 2007, 145 p.

24. Expert forecast on emerging psychosocial risks related to occupational safety and health. Luxembourg, Office for Official Publications of the European Communities, 2007, 126 p.

25. Expert forecast on emerging chemical risks related to occupational safety and health. Luxembourg, European Agency for Safety and Health at Work, 2009, 197 p.

26. Fernándeza F.B., Péreza M.Á.S. Analysis and modeling of new and emerging occupational risks in the context of advanced manufacturing processes. Procedia Engineering. 2015, vol. 100, pp. 1150-1159. DOI: 10.1016/j.proeng.2015.01.478

27. Osnovy otsenki riskov. Okhrana truda - delo kazhdogo. - Evropeiskoe agentstvo po okhrane truda (per. po zakazu Minzdravsotsrazvitiya Rossii) [Basics of risk assessment. Labor protection concerns everybody. European Agency for Health and safety at Work (translation ordered by the RF Ministry for Public Healthcare and Social Development)]. 2008, 56 p.

28. Concha-Barrientos M., Campbell-Lendrum D., Steenland K. Occupational noise: assessing the burden of disease from work-related hearing impairment at national and local levels. WHO Environmental Burden of Disease Series, no. 9. Geneva, World Health Organization, 2004, 41 p.

29. Mazitova N.N., Adeninskaya E.E., Pankova V.B., Simonova N.I., Fedina I.N., Preobrazhenskaya E.A., Bomshtein N.G., Severova M.M., Volokhov L.L. Vliyanie proizvodstvennogo shuma na slukh: sistematicheskii obzor zarubezhnoi literatury [Influence of occupational noise on hearing: systematic review of foreign literature]. Meditsina truda i promyshlennaya ekologiya, 2017, no. 2, pp. 48-53.

30. Principles for modelling dose-response for the risk assessment of chemicals. Environmental Health Criteria 239. Geneva, WHO, 2009, 137 p.

31. Risk assessment and workers' participation. Workshop on making modern OSH legislation. Tirana, Albania, 2012, 34 p. Available at: https://www.ilo.org/wcmsp5/groups/public/---ed dialogue/--lab_admin/documents/presentation/wcms_184162.pdf (18.07.2018).

32. Risk-Controlling the risks in the workplace. Health and Safety Executive, 2014. Available at: http://www.hse.gov.uk/Risk/controlling-risks.htm (18.07.2018).

33. Galizzi M., Tempesti T. Workers' perceptions of risk and occupational injuries. University of Massachusetts Lowell. Risk, Perception, and Response: Conference. Harvard University, 2014, 58 p.

34. Lentz T.J., Dotson G.S., Williams P.R.D., Maier A., Gadagbui B., Pandalai S.P. [et al]. Aggregate exposure and cumulative risk assessment - Integrating occupational and non-occupational risk factors. $J$. $O c$ cup. Environm. Hyg., 2015, vol. 12, pp.112-126.

35. Guidance on risk assessment at work. Luxembourg: Office for Official Publications of the European Communities, 1996, 64 p.

36. Risk management - Risk assessment techniques (IEC/ISO 31010:2009 (EQV). Brussels, CENELEC, 2010, 15 p.

37. Risk Assessment Tool and Guidance (Including guidance on application). No. OQR012. UK: Health and Safety Executive, 2008, 13 p.

38. Kravets V.A., Denisov E.I., Zyabkina T.I. Ispol'zovanie matematicheskogo modelirovaniya dlya prognoza vliyaniya proizvodstvennogo shuma. Okhrana truda na stroitel'stve ob"ektov neftyanoi i gazovoi promyshlennosti. Moscow, Informneftegazstroi, 1980, vol. 1, pp. 18-23.

39. Current Intelligence Bulletin: NIOSH Practices in Occupational Risk Assessment. External review Draft. Regulations.Gov., 2018. Available at: https://www.regulations.gov/document?D=CDC-2018-00600002 (18.07.2018).

Denisov E.I. Noise at a workplace: permissible noise levels, risk assessment and hearing loss prediction. Health Risk Analysis, 2018, no. 3, pp. 13-23. DOI: 10.21668/health.risk/2018.3.02.eng

Received: 19.08.2018

Accepted: 21.09.2018

Published: 30.09.2018 